Research Article

\title{
Comparison of self-medication practice for dysmenorrhoea in medical, nursing and dental students
}

\author{
Jayanthi B., Anuradha H. V.*
}

Department of Pharmacology, M S Ramaiah Medical College, Bangalore -560054, Karnataka, India

Received: 12 February 2016 Accepted: 21 February 2016

\section{*Correspondence to: \\ Dr. Anuradha H. V., \\ Email: dranuradhapharmac @ gmail.com}

Copyright: (C) the author(s), publisher and licensee Medip Academy. This is an openaccess article distributed under the terms of the Creative Commons Attribution NonCommercial License, which permits unrestricted noncommercial use, distribution, and reproduction in any medium, provided the original work is properly cited.

\begin{abstract}
Background: Dysmenorrhea is common in adolescent and young adult females and is responsible for impaired daily activities and significant absenteeism from college among female students. The self-treatment strategy varies among the students. Hence, the present study was done to analyse and compare the selfmedication practice for dysmenorrhoea among medical, nursing and dental students.

Methods: This was a cross-sectional study conducted among 188 female students with dysmenorrhoea in M. S. Ramaiah College Campus, Bangalore which included 62 medical, 63 nursing and 63 dental students. Data was collected with prevalidated questionnaire related to various aspects like demographic data, severity and duration of dysmenorrhoea and pattern of management in the three groups. Data collected was analysed using SPSS version 20.

Results: The mean age of female students with dysmenorrhoea was $19.12 \pm 0.87$ years. $28 \%$ students perceived hormonal changes as causative factor for dysmenorrhoea. About 92 (48.9\%) were on self-medication and 46 (24.5\%) of students used home remedies for dysmenorrhoea. Among 92 students drugs commonly used for self-medication were mefenemic acid+dicyclomine $(67.4 \%)$ followed by paracetamol $(20.7 \%)$, ibuprofen $(5.4 \%)$, dicyclomine $(4.3 \%)$, and diclofenac $(2.2 \%)$. NSAIDS such as mefenamic acid, paracetamol, ibuprofen, diclofenac were used commonly by students in the three groups. Conclusions: Dysmenorrhoea is a common cause for self-medication among young females. Self-medication practice for dysmenorrhoea was seen more in medical students where as non-pharmacological remedies in nursing and dental female students. NSAIDS like mefenamic acid and paracetamol are the mainstay of self-medication for dysmenorrhoea.
\end{abstract}

Keywords: Dysmenorrhoea, Self-medication, Cross-sectional study, Medical students, Nursing students, Dental students

\section{INTRODUCTION}

Dysmenorrhoea is the periodic, spasmodic lower abdomen menstrual crampy pain. ${ }^{1}$ It is the most common problem in adolescent females and young adult females affecting their daily routine activities. ${ }^{2}$ Dysmenorrhoea is responsible for significant absenteeism from college and affects the students' social activities due to mood disturbance. ${ }^{3,4}$ It is usually associated with symptoms like lower back pain, nausea, vomiting, diarrhoea, fatigue and headache. The most common pharmacological treatment for dysmenorrhoea is Non-steroidal antiinflammatory drugs (NSAIDs) like mefenamic acid, ketoprofen, ibuprofen, paracetamol and diclofenac. ${ }^{5}$
NSAIDs acts by inhibiting cyclooxygenase enzyme, resulting in reduced prostaglandin production and less uterine contractions and reduced menstrual discomfort. NSAIDS are easily available as over the counter drugs and hence this has led to self-medication with NSAIDS for primary dysmenorrhoea among adolescent and young females. Self-medication is termed as the use of medicines which are designed and labelled for use without medical supervision and approved as safe and effective for such use. The drugs used for self-medication are called Non-prescription or over the counter (OTC) drugs and are available without doctor's prescription through pharmacies. ${ }^{6}$ Hence, the present study has been taken up to analyse the self- medication practice and to 
analyse the drugs commonly used among medical, nursing and dental students.

The objective of the study is to analyse the pattern of drugs used as self-medication for dysmenorrhoea among female students and to compare self-medication practice for dysmenorrhoea in medical, nursing and dental female students.

\section{METHODS}

This was a cross-sectional study conducted in Medical \& Paramedical college campus, Bangalore with prior approval from Institutional Ethics Committee. Female students aged $\geq 18$ years with dysmenorrhoea from medical, nursing and dental colleges and willing to give written informed consent were included. A pre-validated questionnaire was used to collect data such as demographic characteristics, duration of dysmenorrhoea, amount of severity of menstrual flow, the symptoms associated with dysmenorrhoea such as abdominal pain, headache, and mood disturbance. The remedial methods varied among the students and the method practiced by each student such as self-medication, home remedies, hot water bath, sleep, rest, physical exercise and consultation with doctor were recorded. The impact of dysmenorrhoea on their daily routine activities, social activities, and sleep disturbances such as insomnia, increased stress, college absenteeism and academic performance were recorded. The perception of cause of dysmenorrhoea varied among the students and was recorded. The source of information for self- medication and source of procuring the drugs for self-medication among the students, the number and type of drugs used were also recorded.

Based on the previous study by Cheng HF, Lin YF, et al, total of 186 female students with dysmenorrhoea (62 in each group) was required for $80 \%$ power and $95 \%$ confidence interval with alpha error of $5 \%$ for the study. ${ }^{7}$ Statistical analysis was done using SPSS version 20. The demographic characteristics of the female students with dysmenorrhoea included in our study, duration of discomfort and the associated symptoms, students' perception about cause of dysmenorrhoea were analysed by descriptive statistics. The self-remedial methods followed by the students for dysmenorrhoea such as selfmedication, home remedies and the drugs used for selfmedication for dysmenorrhoea were analysed by chi square test, $\mathrm{p}<0.05$ was considered as statistically significant.

\section{RESULTS}

This cross-sectional study included 188 female students with dysmenorrhoea from M.S. Ramaiah College campus and comprised of 62 medical students, 63 nursing students and 63 dental students. All students were in the second year of their respective professional course. The mean age of 188 female students with dysmenorrhoea was $19.12 \pm 0.87$ years; of which mean age in medical group was $19.07 \pm 1.28$ years, $19.1 \pm 0.86$ years in para-medical group and $19.2 \pm 0.75$ years in non-medical group ( $>0.05)$. The mean body mass index (BMI) of all students was $23.4 \pm 1.2 \mathrm{~kg} / \mathrm{m}^{2} .94 .8 \%$ of medical, $62.5 \%$ of nursing and $92 \%$ of dental female students were aware of the term dysmenorrhoea. Menstrual cycle pattern including regularity, duration of menstrual cycle and amount of flow during menstrual cycle were noted (Table 1). The symptoms experienced by students with dysmenorrhoea were abdominal cramps, leg ache, mood changes, anxiety, backache, tiredness and acne problems (Table 2). The number of students experiencing menstrual discomfort and premenstrual discomfort (Table 3) and duration of discomfort during the cycle was recorded (Figure 1).

Table 1: Characteristics of the menstrual cycle in female students with dysmenorrhoea.

\begin{tabular}{|c|c|c|c|}
\hline & $\begin{array}{l}\text { Medical } \\
(n=62) \\
\mathbf{N}(\%)\end{array}$ & $\begin{array}{l}\text { Nursing } \\
(\mathbf{n}=63) \\
\mathbf{N}(\%)\end{array}$ & $\begin{array}{l}\text { Dental } \\
(n=63) \\
N(\%)\end{array}$ \\
\hline $\begin{array}{l}\text { Regular } \\
\text { menstrual cycle }\end{array}$ & $43(69.4)$ & $52(82.5)$ & $47(74.6)$ \\
\hline $\begin{array}{l}\text { Irregular } \\
\text { menstrual cycle }\end{array}$ & $19(30.6)$ & $11(17.5)$ & $16(25.4)$ \\
\hline \multicolumn{4}{|c|}{ Duration of menstrual period } \\
\hline 1-2 days & $03(04.8)$ & $03(04.7)$ & $5(07.9)$ \\
\hline 3-5 days & $36(58.1)$ & $29(46.0)$ & $41(65.1)$ \\
\hline$>5$ days & $23(37.1)$ & $31(49.2)$ & $17(26.9)$ \\
\hline \multicolumn{4}{|l|}{ Amount of flow } \\
\hline $\begin{array}{l}\text { Little (1-2 } \\
\text { pads/day) }\end{array}$ & $34(54.8)$ & $28(44.4)$ & $37(58.7)$ \\
\hline $\begin{array}{l}\text { Moderate (2-3 } \\
\text { pads/day) }\end{array}$ & $16(25.8)$ & $20(31.7)$ & $12(19.0)$ \\
\hline $\begin{array}{l}\text { Heavy (>3 } \\
\text { pads/day) }\end{array}$ & $12(19.4)$ & $15(23.8)$ & $14(22.2)$ \\
\hline \multicolumn{4}{|c|}{ Interval between each menstrual cycle } \\
\hline$<21$ days & $14(22.6)$ & $18(28.6)$ & $15(23.8)$ \\
\hline 21-35 days & $36(58.1)$ & $34(53.9)$ & $38(60.3)$ \\
\hline$>35$ days & $13(20.9)$ & $11(17.5)$ & $10(15.9)$ \\
\hline
\end{tabular}

$\mathrm{N}=$ number of students

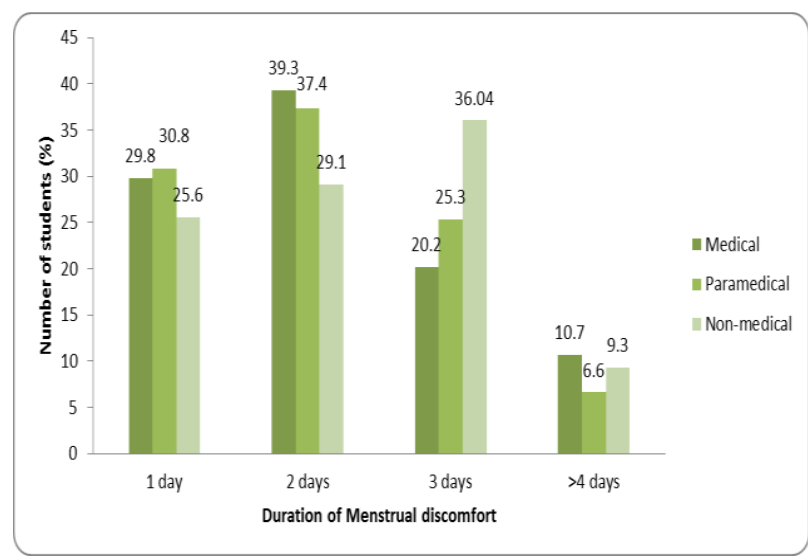

Figure 1: Bar chart showing duration of menstrual discomfort among students with dysmenorrhoea. 
Table 2: Symptoms associated with menstrual discomfort experienced by female students with dysmenorrhoea.

\begin{tabular}{|llll|}
\hline $\begin{array}{l}\text { Symptoms } \\
\text { during } \\
\text { dysmenorrhoea }\end{array}$ & $\begin{array}{l}\text { Medical } \\
(\mathbf{N})\end{array}$ & $\begin{array}{l}\text { Nursing } \\
(\mathbf{N})\end{array}$ & $\begin{array}{l}\text { Dental } \\
(\mathbf{N})\end{array}$ \\
\hline Nausea & 11 & 9 & 07 \\
\hline Vomiting & 05 & 09 & 07 \\
\hline Dizziness & 10 & 11 & 10 \\
\hline Headache & 11 & 20 & 07 \\
\hline Backache & 32 & 28 & 29 \\
\hline Tiredness & 22 & 32 & 17 \\
\hline Myalgia & 23 & 10 & 16 \\
\hline Anxiety & 20 & 21 & 12 \\
\hline Mood & 33 & 26 & 29 \\
\hline Diarrhoea & 09 & 04 & 02 \\
\hline Breast heaviness & 12 & 13 & 08 \\
\hline Leg cramps & 28 & 28 & 15 \\
\hline Leg swelling & 02 & 02 & 05 \\
\hline Abdominal pain & 38 & 33 & 42 \\
\hline Acne & 22 & 23 & 27 \\
\hline Sweating & 02 & 03 & 00 \\
\hline Nenumber stadent & & & \\
\hline
\end{tabular}

$\mathrm{N}=$ number of students

Table 3: Students with discomfort during menstrual cycle and premenstrual period.

\begin{tabular}{|llll|}
\hline $\begin{array}{l}\text { Menstrual } \\
\text { Discomfort }\end{array}$ & $\begin{array}{l}\text { Medical } \\
(\mathbf{n}=62) \\
\mathbf{N}(\%)\end{array}$ & $\begin{array}{l}\text { Nursing } \\
(\mathbf{n}=63)\end{array}$ & $\begin{array}{l}\text { Dental } \\
(\mathbf{n}=63)\end{array}$ \\
\hline $\begin{array}{l}\text { During } \\
\text { menstrual } \\
\text { cycle }\end{array}$ & $38(61.3)$ & $32(50.8)$ & $45(71.4)$ \\
\hline $\begin{array}{l}\text { During } \\
\text { premenstrual } \\
\text { period }\end{array}$ & $14(22.6)$ & $17(26.9)$ & $12(19.0)$ \\
\hline Both & $11(17.7)$ & $14(22.2)$ & $6(9.5)$ \\
\hline
\end{tabular}

$\mathrm{n}, \mathrm{N}=$ number of students

Out of total 188 female students with dysmenorrhoea; 73 (38.8\%) students described dysmenorrhoea problem as stressful, $54(28.7 \%)$ students had difficulty in their social activities and $32(17.1 \%)$ students developed insomnia due to dysmenorrhoea. In $67 \quad(35.6 \%)$ students dysmenorrhoea affected their daily activities, $16(8.5 \%)$ students reported college absenteeism and 11 (5.9\%) students reported poor academic performance. The causative factor of primary dysmenorrhoea perceived by the students were hormonal changes, stress and familial condition mainly in medical group when compared with other groups $(p<0.05)$. Lack of exercise was regarded as the cause of dysmenorrhoea mainly by dental students $(\mathrm{p}<0.05)$. Consumption of coffee was regarded as diet factor responsible for dysmenorrhoea by nursing students $(\mathrm{p}<0.05)$ (Figure 2).
The remedial methods followed by students with dysmenorrhoea were self-medication, home remedy, exercise, rest, sleep; and only few had consultation with doctor (Figure 3). Pharmacological methods such as selfmedication was mainly practised by medical followed by dental and nursing students with dysmenorrhoea $(\mathrm{p}<0.05)$. Home remedy was mainly practised by nursing students followed by dental students $(\mathrm{p}<0.05)$. Physical exercise was mainly practised by dental students $(\mathrm{p}<0.05)$. Other methods practised by the students were hot water bath, rest and sleep (Figure 4). The source of information of drugs for dysmenorrhoea among the students who practiced self-medication was from family members in 34 $(30.4 \%)$ students, from pharmacist in 18 (13.04\%) students and the rest of the students got the information from internet and books. $56.9 \%$ of students purchased the drugs from pharmacy, $30.6 \%$ obtained the drugs from relatives and friends and $12.5 \%$ used left over medication available at home.

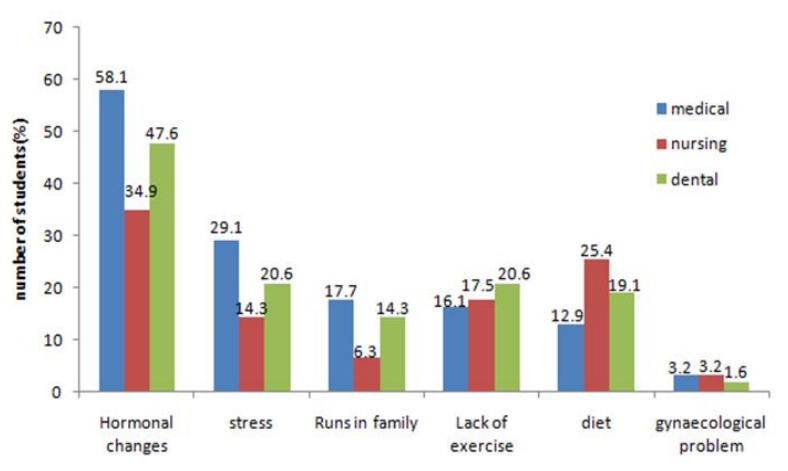

Figure 2: Bar chart showing the cause of dysmenorrhoea as percieved by the medical, paramedical and nonmedical students with dysmenorrhoea.

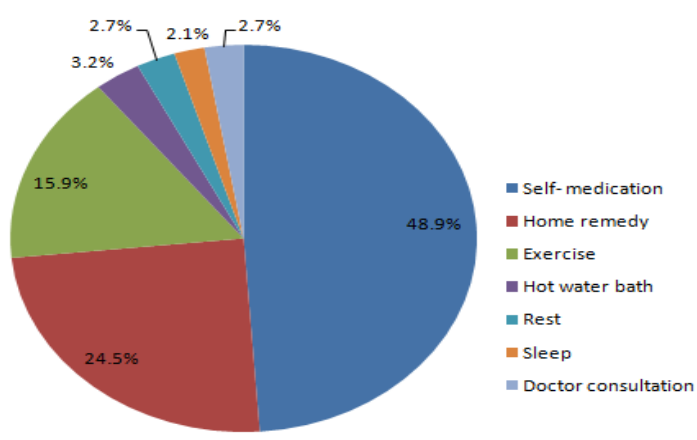

Figure 3: Pie chart showing remedial methods practiced by female students with dysmenorrhoea (expressed as percentage).

The drugs used for self- medication by the female students with dysmenorrhoea were fixed drug combination of mefenamic acid and dicyclomine in 62 $(67.4 \%)$, paracetamol in $19(20.7 \%)$, ibuprofen in 5 $(5.4 \%)$, dicyclomine in $4(4.3 \%)$ and diclofenac in 2 $(2.2 \%)$. The fixed drug combination of mefenamic acid and dicyclomine followed by paracetamol were 
commonly used by students in all three groups (Figure 5). Single drug was used by $74(80.4 \%)$ students, $2-3$ types of medication were used by $18(19.6 \%)$ students. $68(73.9 \%)$ students experienced relief with single dose of drug during the discomfort and $24(26.1 \%)$ students consumed the drug prior to starting of menstrual period in anticipation of the discomfort.

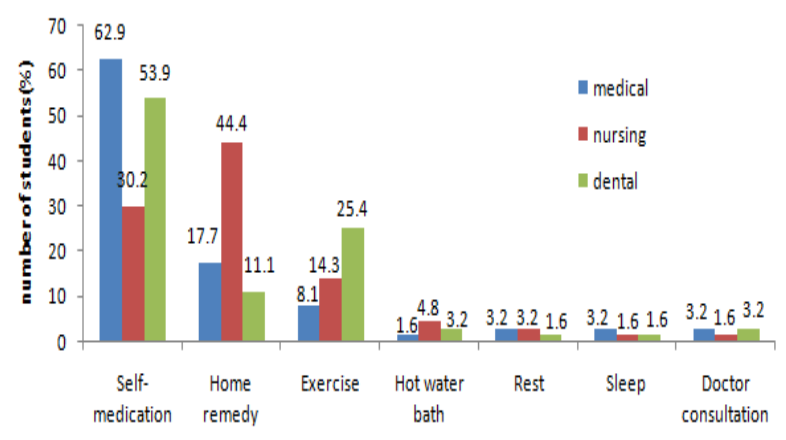

Figure 4: Bar chart showing the remedial methods used for dysmenorrhoea by medical, nursing and dental students.

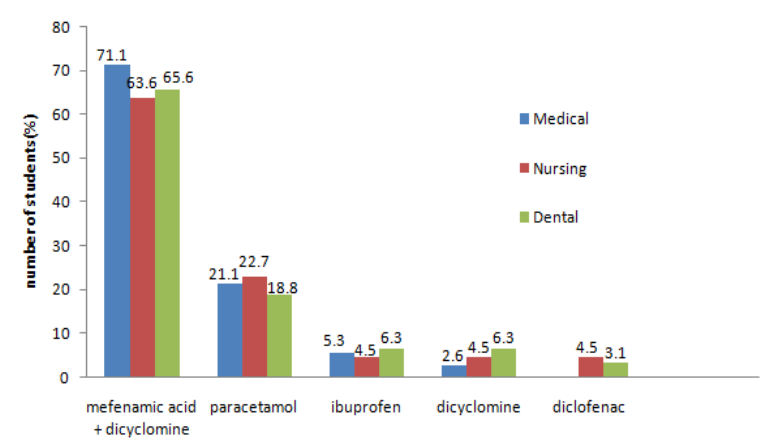

Figure 5: Bar chart showing the drugs used for selfmedication by the medical, nursing and dental students with dysmenorrhoea.

\section{DISCUSSION}

In this cross sectional study, $75.5 \%$ students with regular cycles had dysmenorrhoea. All the medical students were aware of the term dysmenorrhoea when compared to nursing and dental students. The medical students considered hormonal changes, stress as the causative factors of dysmenorrhoea and considered it as familial condition probably due to their awareness about the problem, whereas nursing and dental students regarded stress, diet and lack of exercise as causative factors of dysmenorrhoea. The menstrual discomfort was associated with leg cramps, abdominal cramps, headache, generalized body ache, tiredness, nausea, vomiting, mood changes which lead to increased stress among the students and their daily activities during discomfort were limited. ${ }^{8,9}$

We noted the impact of dysmenorrhoea on social activities of the students resulting in college absenteeism and poor academic performance which is similar to the observations made in previous studies. ${ }^{9-11}$ Nursing and dental students reported significantly greater limitation of daily activities due to dysmenorrhea than medical students $(\mathrm{p}<0.05)$. College absenteeism was seen in all the groups as in previous study $(\mathrm{p}>0.0 .5){ }^{11}$

Our study showed that self-remedial methods used by the students for dysmenorrhoea were self-medication and non-pharmacological remedies such as home remedy, hot water bath, exercise, rest and sleep similar to previous studies by Eryilmaz et al and Connel et al. ${ }^{12,13}$ Medical students used self-medication more when compared to nursing and dental students because of awareness of drugs used for dysmenorrhoea. Nursing and dental students used non-pharmacological remedies more commonly for dysmenorrhoea probably because of inadequate knowledge about drugs used for dysmenorrhoea; and also they experienced relief with non-pharmacological methods and considered it much safer than drugs. The students experienced discomfort during menstrual cycle, premenstrual period and some reported both premenstrual and menstrual discomfort which added to increased stress among the female students with dysmenorrhoea. The students used mainly mefenamic acid and dicyclomine as fixed drug combination followed by paracetamol in the three groups as self-medication for dysmenorrhoea. The other drugs used were ibuprofen, diclofenac and dicyclomine. Hence analgesics and antispasmodics were commonly used. Among analgesics, NSAIDS were commonly used as self-medication similar to previous studies. ${ }^{5,11,14,15}$

Dysmenorrhoea is a common problem among adolescent and young adult females. Self-medication practice is very commonly seen in female students with dysmenorrhoea. Medical students used self-medication method more commonly for dysmenorrhoea where as non-pharmacological remedies were used more commonly by nursing and dental female students. NSAIDS such as mefenamic acid and paracetamol were used commonly for self- medication for dysmenorrhoea. Since NSAIDs and other drugs used commonly for selfmedication can result in adverse drug (untoward) reactions, hence it is important to consult registered practitioners and to consume drugs only in severe discomfort.

Funding: No funding sources Conflict of interest: None declared

Ethical approval: The study was approved by the Institutional Ethics Committee

\section{REFERENCES}

1. Kolhe S, Deb S. Dysmenorrhea. Obstet Gynaecol Reprod Med. 2011;21(11):311-6.

2. Proctor M, Farquhar C. Diagnosis and management of dysmenorrhoea. BMJ. 2006;332:1134-8. 
3. Harel Z. Dysmenorrhea in adolescents and young adults: etiology and management. J Pediatr Adolesc Gynecol. 2006;19(6):363-71.

4. Sultan C, Gaspari L, Paris F. Adolescent dysmenorrhea. Endocr Dev. 2012;22:171-80.

5. Lefebvre G, Pinsonneault O, Antao V, Black A, Burnett M, Feldman et al. Primary dysmenorrhea consensus guidelines. 2005;169. Available at http://sogc.org/wp-content/uploads/2013/01/169ECPG-December2005.pdf. Accessed on 10 Feb 2016.

6. Hughes CM, McElnay JC, Fleming GF. Benefits and risks of self-medication. Drug Saf. 2001;24(14):1027-37.

7. Cheng HF, Lin YH. Selection and efficacy of selfmanagement strategies for dysmenorrheal in young Taiwanese women. J Clin Nurs. 2011;20(7-8):101825.

8. Pembe AB, Ndolele NT. Dysmenorrhoea and coping strategies among secondary school adolescents in Ilala District, Tanzania. East Afr J Public Health. 2011;8(3):232-6.

9. Rahma AK, Anbarin AB. Prevalence and impact of dysmenorrhoea among Omani high school students. SQU Med J. 2011;11(4):485-91.
10. Banikarim C, Chacko M, Kelder SH. Prevalence and impact of dysmenorrhea on hispanic female adolescents. Arch Pediatr Adolesc Med. 2000;154:1226-9.

11. Ortiz MI. Primary dysmenorrhea among Mexican university students: prevalence, impact and treatment. Eur J Obstet Gynecol Reprod Biol. 2010;152(1):73-7.

12. Eryilmaz G, Ozdemir F. Evaluation of menstrual pain management approaches by Northeastern Anatolian adolescents. Pain Manag Nurs. 2009;10(1):40-7.

13. O'Connell K, Davis AR, Westhoff C. Self-treatment patterns among adolescent girls with dysmenorrheal. J Pediatr Adolesc Gynecol. 2006;19:285-9.

14. Sugumar R, Krishnaiah V, Channaveera GS, Mruthyunjaya S. Comparison of the pattern, efficacy, and tolerability of self-medicated drugs in primary dysmenorrhea: a questionnaire based survey. Indian J Pharmacol. 2013;45:180-3.

15. Dawood MY. Primary dysmenorrhea: advances in pathogenesis and management. 2006;108(2):428-41.

Cite this article as: Jayanthi B, Anuradha HV. Comparison of self-medication practice for dysmenorrhoea in medical, nursing and dental students. Int J Basic Clin Pharmacol 2016;5:269-73. 